\title{
A multi-proxy lacustrine record of Holocene climate change on northeastern Baffin Island, Arctic Canada
}

\author{
Jason P. Briner ${ }^{\mathrm{a}, *}$, Neal Michelutti ${ }^{\mathrm{b}}$, Donna R. Francis ${ }^{\mathrm{c}}$, Gifford H. Miller ${ }^{\mathrm{d}}$, Yarrow Axford ${ }^{\mathrm{d}}$, \\ Matthew J. Wooller ${ }^{\mathrm{e}}$, Alexander P. Wolfe ${ }^{\mathrm{b}}$ \\ a Geology Department, University at Buffalo, Buffalo, NY 14260, USA \\ ${ }^{\mathrm{b}}$ Department of Earth and Atmospheric Sciences, University of Alberta, Edmonton, AB T6G 2E3, USA \\ ${ }^{\mathrm{c}}$ Department of Geosciences, University of Massachusetts, Amherst, MA 01003, USA \\ ${ }^{\mathrm{d}}$ Department of Geological Sciences and the Institute of Arctic and Alpine Research, University of Colorado, Boulder, CO 80303, USA \\ e Alaska Stable Isotope Facility, Water and Environmental Research Center and School of Fisheries and Ocean Sciences, University of Alaska, Fairbanks, \\ AL 99775-5860, USA
}

Received 25 April 2005

Available online 7 February 2006

\begin{abstract}
Reconstructions of past environmental changes are critical for understanding the natural variability of Earth's climate system and for providing a context for present and future global change. Radiocarbon-dated lake sediments from Lake CF3, northeastern Baffin Island, Arctic Canada, are used to reconstruct past environmental conditions over the last 11,200 years. Numerous proxies, including chironomidinferred July air temperatures, diatom-inferred lakewater $\mathrm{pH}$, and sediment organic matter, reveal a pronounced Holocene thermal maximum as much as $5^{\circ} \mathrm{C}$ warmer than historic summer temperatures from $\sim 10,000$ to 8500 cal yr B.P. Following rapid cooling $\sim 8500$ cal yr B.P., Lake CF3 proxies indicate cooling through the late Holocene. At many sites in northeastern Canada, the Holocene thermal maximum occurred later than at Lake CF3; this late onset of Holocene warmth is generally attributed to the impacts of the decaying Laurentide Ice Sheet on early Holocene temperatures in northeastern Canada. However, the lacustrine proxies in Lake CF3 apparently responded to insolation-driven warmth, despite the proximity of Lake CF3 to the Laurentide Ice Sheet and its meltwater. The magnitude and timing of the Holocene thermal maximum at Lake CF3 indicate that temperatures and environmental conditions at this site are highly sensitive to changes in radiative forcing.

(C) 2005 University of Washington. All rights reserved.
\end{abstract}

Keywords: Climate change; Arctic; Lacustrine record; Holocene thermal maximum; Chironomid; Diatom; Organic matter

\section{Introduction}

Information on past environmental change provides a context for present and future global change and informs our understanding of the underlying mechanisms of natural climate variability. High latitude regions have experienced the greatest climatic and ecological changes since the last deglaciation, and they are expected to be exceptionally susceptible to anthropogenic warming due to cryospherealbedo feedbacks involving changing sea ice, boreal forest, and glacier extents (Overpeck et al., 1997; CAPE, 2001;

\footnotetext{
* Corresponding author. Fax: +1 7164953999.

E-mail address: jbriner@buffalo.edu (J.P. Briner).
}

Moritz et al., 2002; Smol et al., 2005). Quantitative records of past climate change can provide constraints on the magnitude of future changes in the Arctic (e.g., Bigler et al., 2002; Kerwin et al., 2004). Although recent progress has been made toward obtaining spatially dense records of Holocene climate change (Kaufman et al., 2004), quantitative records are relatively few and far between.

Despite relatively stable climate forcings compared with glacial periods, the Holocene interglacial experienced dramatic environmental changes. These include, for example, temperature changes significant enough to cause the collapse of Norse settlements on Greenland (Barlow et al., 1997) and periodic changes in ocean sedimentation that may follow the cycle of solar variability (Bond et al., 2001). Lake sediments are valuable archives of environmental changes, because lakes 
are geographically widespread and their sediments are often continuous and datable (e.g., Wolfe et al., 2004). In addition, multiple physical, chemical and biological proxies can be analyzed from lake sediment cores, which can provide reliable indicators of past environmental and climatic change (e.g., Wolfe et al., 2000; Rosén et al., 2001; Bigler et al., 2002; Larocque and Bigler, 2004).

Although records of Holocene conditions in the Baffin Bay region (Fig. 1) exist from western Greenland (Kelly, 1985; Willemse and Törnqvist, 1999; Bennike, 2000) and Baffin Bay itself (Dyke et al., 1996; Levac et al., 2001), highresolution records (sub-centennial scale) from Baffin Island are lacking. Ice cores provide important insights of Holocene climate variability for selected sites on southern Baffin, Devon, and Ellesemere islands (Fig. 1; e.g., Fisher et al., 1995, 1998), but Holocene lake sediment records from Baffin Island thus far are either coarsely resolved or do not encompass the entire Holocene. This study provides a multi-proxy reconstruction of Holocene $(11,200 \mathrm{cal}$ yr B.P. to present) climate change from a lake sediment core from eastern Baffin Island. Multiple physical, chemical, and biological proxies all register a well-defined period of warmer-than-present conditions between $\sim 10,200$ and 8500 cal yr B.P. followed by cooling during the middle and late Holocene.
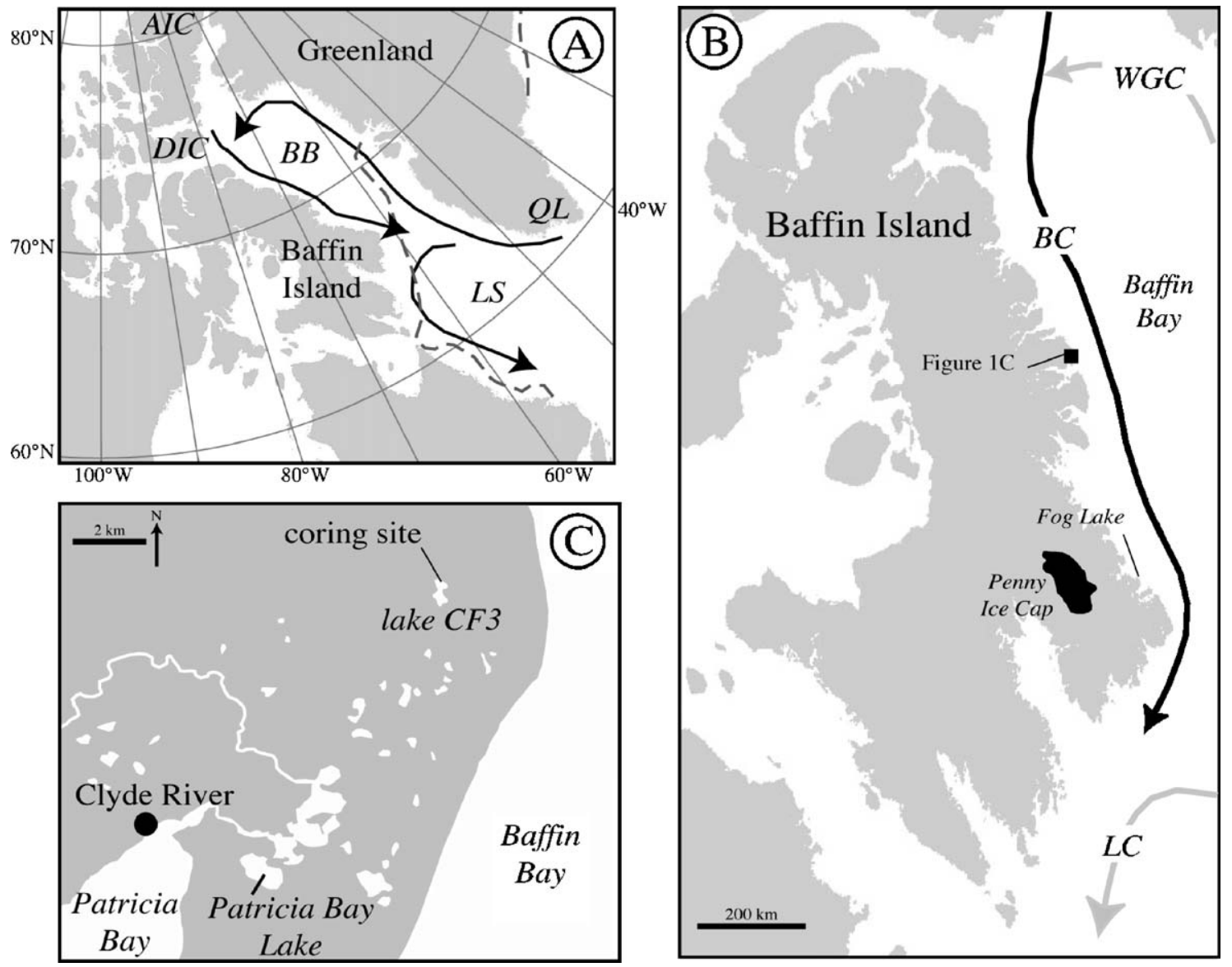

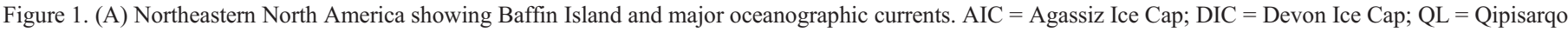

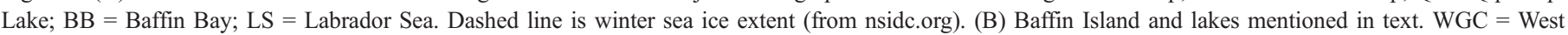
Greenland Current; BC = Baffin Current, LC = Labrador Current. (C) The Clyde Foreland and location of Lake CF3. 
has gradually declined since $12,000-10,000$ cal yr B.P., when total insolation at $60^{\circ} \mathrm{N}$ was almost $10 \%$ higher than at present; Berger and Loutre, 1991) and seasonality of insolation (which has also gradually declined through the Holocene); 2) local and regional deglaciation (Dyke et al., 2002; Briner et al., 2005); and 3) the relative abundance of warm southerly and cold northerly water masses in Baffin Bay, which are related to oceanographic conditions in the North Atlantic (Dyke et al., 1996). Advection of relatively warm subarctic waters into Baffin Bay via the West Greenland Current (WGC) transports heat to the Baffin Bay region (Fig. 1). Modern temperature gradients illustrate the importance of WGC to temperatures around Baffin Bay. For example, multi-year sea ice develops in northern Baffin Bay beyond the influence of the WGC, whereas winter sea ice rarely forms along much of the West Greenland coast due to the influence of the WGC on sea surface temperatures (Jacobs et al., 1985). Oceanographic and sea-ice conditions in turn affect terrestrial climate. For example, the northern limit of dwarf birch, a thermophilous shrub requiring relatively warm summer temperatures, occurs near the boundary between Arctic (Baffin Current) and subarctic (WGC) waters on both sides of Baffin Bay (Jacobs et al., 1985).

\section{Methods}

A 180-cm-long sediment core was recovered from the deepest portion of Lake CF3 in May 2002, using a sledmounted percussion coring system (Nesje, 1992). The core was kept cool until transported to the laboratory where it was split lengthwise, described, photographed, and subsampled. In May 2003, a 21-cm-long surface core with an intact sediment-water interface was obtained adjacent to the original coring site using a gravity-type corer. The surface core was sectioned in the field, using an upright extruding device, at 0.5 $\mathrm{cm}$ for the first $5 \mathrm{~cm}$ and at $1 \mathrm{~cm}$ thereafter. Volumetric subsamples were taken from the percussion core every $2 \mathrm{~cm}$ for wet and dry bulk density and hydroscopic moisture calculations, and for magnetic susceptibility (MS). Grain size was measured every 10 to $15 \mathrm{~cm}$ using a Malvern laser diffraction particle size analyzer. Percent loss-on-ignition at $550^{\circ} \mathrm{C}$ (LOI; e.g., Dean, 1974; Heiri et al., 2001) was measured every $1 \mathrm{~cm}$ in the percussion core and on every sample in the surface core; LOI flux was calculated by multiplying \%LOI by dry bulk density and dividing by the length of time represented by a sample.

Samples from Lake CF3 sediments were analyzed for stable carbon and nitrogen isotopes of total organic carbon (TOC) and nitrogen (TON) every 0.5 to $1 \mathrm{~cm}$ in the surface core and every $\sim 5 \mathrm{~cm}$ in the percussion core $(n=54)$. Diatoms were counted every 0.5 to $1 \mathrm{~cm}$ in the surface core and every 2 to $3 \mathrm{~cm}$ in the percussion core $(n=80)$, and chironomids were analyzed every 20 to $30 \mathrm{~cm}(n=15)$. The sub-samples for stable isotope analysis were freeze dried and reacted with concentrated, fuming $\mathrm{HCl}$ in an airtight container to remove any carbonates (Harris et al., 2001).
An aliquot ( $~ 5.1$ to $6.0 \mathrm{mg})$ of each of these prepared samples was weighed into a tin capsule, which was crimped and introduced into the autosampler (A2100) of a CE Instruments, NA 2500 series, elemental analyzer at the Alaska Stable Isotope Facility. Purified combustion gases $\left(\mathrm{CO}_{2}\right.$ and $\left.\mathrm{N}_{2}\right)$ were separated prior to entering a Finnigan Conflo III interface and the stable isotope ratio mass spectrometry (Finnigan MAT, Delta ${ }^{\text {plus } X P) . ~ T h e ~ r e s u l t s ~ a r e ~}$ presented in standard delta notation. Peptone was analyzed (every 10th sample) as a check on the analytical precision throughout the analyses, which was $\pm 0.16 \%$ for $\delta^{15} N$ $(N \%= \pm 1.0)$ and was $\pm 0.16 \%$ for $\delta^{13} \mathrm{C}(\mathrm{C} \%= \pm 3.0 ; n=12)$.

Diatom preparation followed standard protocols for siliceous microfossils (Wilson et al., 1996). A minimum of 300 valves were identified and enumerated for each interval using a Leica DMRB microscope equipped with Nomarski DIC optics at $1000 \times$ magnification. Diatom taxa were identified primarily following Krammer and Lange-Bertalot (19861991) and Patrick and Reimer (1966, 1975). The calibration model of Joynt and Wolfe (2001), developed from 61 Baffin Island lakes with similar catchment geology to Lake CF3, was used to derive the diatom $\mathrm{pH}$ inferences. The $\mathrm{pH}$ inference model, slightly modified from its original form in Joynt and Wolfe (2001), was developed with $\mathrm{C}^{2}$ (Juggins 2003) using weighted averaging regression with classical deshrinking and cross-validation by bootstrapping. The model showed a relatively good relationship between the measured and diatom-inferred $\mathrm{pH}$ values $\left(r_{\text {boot }}=0.66, P<0.01\right.$, $\mathrm{RMSE}_{\text {boot }}=0.34$ ), with no significant trends in the residuals $(r=0.00)$.

Sediment samples selected for chironomid analysis were deflocculated with warm $5 \% \mathrm{KOH}$, rinsed through a $100-\mu \mathrm{m}$ mesh sieve, and sorted using a Bogorov counting tray under $50 \times$ magnification (Walker, 2001). At least 50 head capsules per sample were identified to the lowest possible taxonomic level, except that at two levels (composite depths of 60 and $144 \mathrm{~cm}$ ) only 37 head capsules were counted. The transfer function used to estimate chironomid-inferred summer water and mean July air temperatures is based on a training set of modern samples from 68 sites spanning from the Canadian High Arctic to the northeastern US (Walker et al. 1997). The model used for reconstructions is a weighted averaging regression with inverse deshrinking and tolerance downweighting, and cross-validation by jackknifing. Temperature inferences are made using the computer software $\mathrm{C}^{2}$. For mean July air temperature, the model has an $r$ of $0.94(P<$ 0.01 ) and root mean square error of prediction (RMSEP) of $1.53^{\circ} \mathrm{C}$.

The chronology is based on six accelerator mass spectrometry (AMS) ${ }^{14} \mathrm{C}$ measurements on pieces of aquatic moss from the percussion core, and one macrofossil AMS ${ }^{14} \mathrm{C}$ age from the surface core. By dating aquatic macrofossils from Lake CF3, situated in a crystalline bedrock basin, we avoid oldcarbon issues that can arise when dating arctic lake sediments (Wolfe et al., 2004). Samples were picked and prepared at the INSTAAR Laboratory for AMS Radiocarbon Preparation and Research at the University of Colorado and measured at the 


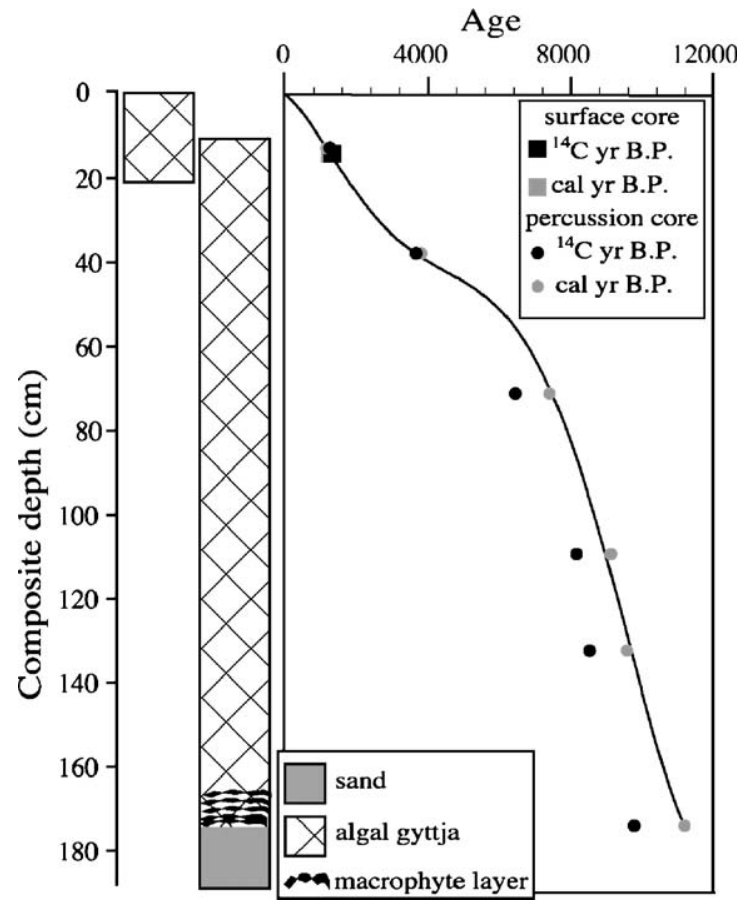

Figure 2. Sediment lithostratigraphy and ${ }^{14} \mathrm{C}$ ages. The age model is shown by a thin black line $\left(r^{2}=0.99\right)$.

National Ocean Sciences AMS Facility at Woods Hole Oceanographic Institution.

\section{Results}

The lithostratigraphy of the Lake CF3 core consists of 174 $\mathrm{cm}$ of algal gyttja (combined surface and percussion core) that overlies $15 \mathrm{~cm}$ of inorganic, gray fine sand at the core base. A 5-cm-thick macrofossil-rich layer sits immediately above the basal sand, and thinner ( $\sim 1 \mathrm{~cm}$ or less) layers of macrofossils are scattered throughout the gyttja portion of the core. The ${ }^{14} \mathrm{C}$ ages provide an age-depth model that shows decreasing sedimentation throughout the Holocene (Fig. 2; Table 1). The ${ }^{14} \mathrm{C}$ age from $2-\mathrm{cm}$ depth in the percussion core corresponds to the same interpolated ${ }^{14} \mathrm{C}$ age at a depth of $13 \mathrm{~cm}$ in the surface core, indicating that the top $11 \mathrm{~cm}$ of sediment was lost during percussion coring and/or core packaging. Splicing the surface core onto the percussion core created a composite depth profile (Fig. 2).

The sand at the core base has a high MS and bulk density, and low moisture content (Fig. 3). The lowest values in MS and bulk density, and the highest values in moisture content, occur between 10,800 and 8000 cal yr B.P. Magnetic susceptibility and bulk density increase slightly after 8000 cal yr B.P., whereas moisture content decreases slightly over the same interval. The grain size data from the gyttja portion of the core show no overall trend (Fig. 3).

The onset of organic matter accumulation in Lake CF3 occurs between 11,000 and 10,800 cal yr B.P. and peaks between 10,300 and $9000 \mathrm{cal} \mathrm{yr} \mathrm{B.P.} \mathrm{(Fig.} \mathrm{4).} \mathrm{Following} \mathrm{a} \mathrm{sharp}$ decline in organic matter content between 9000 and $8500 \mathrm{cal} \mathrm{yr}$ B.P., values steadily decline through the Holocene, with some modest fluctuations, before rising to early Holocene values over the last $\sim 100$ years. To remove the effects of changing sedimentation rate on LOI, we also calculated the LOI flux, which reveals a broader peak between $\sim 10,800$ and 9000 cal yr B.P. (Fig. 4). The $\% C_{\mathrm{TOC}}$ and the LOI values have a strong correlation $(r=0.96, P<0.01)$, which is expected for small lakes in crystalline bedrock terrains. The $\% C_{\text {TOC }}$ and $\% N_{\text {TON }}$ also correlate strongly $(r=0.95, P<0.01)$. The $C: N$ values range from $\sim 8$ to $\sim 17$, are lowest before $10,000 \mathrm{cal}$ yr B.P., maintain high values between 10 and $\sim 7$ cal yr B.P., and fluctuate between values of $\sim 11$ and $\sim 16$ throughout the middle and late Holocene (Fig. 4). Diatom valve concentrations rise at $10,000 \mathrm{cal}$ yr B.P. (from a few hundred valves $\mathrm{g}^{-1}$ to a few thousand valves $\mathrm{g}^{-1}$ ), remain relatively high until $6500 \mathrm{cal}$ yr B.P., and remain relatively low (500 to 700 valves $\mathrm{g}^{-1}$ ) throughout the late Holocene. Diatom valve concentration decreases (down to $\sim 250$ valves $\mathrm{g}^{-1}$ ) following $3000 \mathrm{cal}$ yr B.P. until a sharp increase to $>1000$ valves $\mathrm{g}^{-1}$ occurs in the last 100 years (Fig. 4).

The $\delta^{13} C_{\text {TOC }}$ and $\delta^{15} N_{\text {TON }}$ values show large shifts $(-19.4 \%$ to $-26.6 \%$ and $-0.9 \%$ to $4.1 \%$, respectively) throughout the record (Fig. 5). The $\delta^{13} C_{\text {TOC }}$ profile shows a large fluctuation $(\sim 6 \%)$ between 11,000 and $10,000 \mathrm{cal}$ yr B.P., maintains relatively high values between 10,000 and $\sim 6000$ cal yr B.P. $(\sim-22 \%)$, and drops to lower values $(\sim-25 \%)$ in the late Holocene. The $\delta^{15} N_{\text {TON }}$ values are highest $(\sim 4 \%)$ in the lowermost gyttja $\sim 11,000$ cal yr B.P., sharply decline to lower

Table 1

Radiocarbon ages from lake CF3

\begin{tabular}{|c|c|c|c|c|c|c|c|}
\hline $\begin{array}{l}\text { Core depth } \\
(\mathrm{cm})^{\mathrm{a}}\end{array}$ & $\begin{array}{l}\text { Composite } \\
\text { depth }(\mathrm{cm})\end{array}$ & Material dated & $\begin{array}{l}\delta^{13} \mathrm{C} \\
(\% \text { PDB) }\end{array}$ & $\begin{array}{l}\text { Lab } \\
\text { number }\end{array}$ & $\begin{array}{l}\text { Radiocarbon age } \\
\left({ }^{14} \mathrm{C} \text { yr B.P. }\right)\end{array}$ & $\begin{array}{l}\text { Calibrated age } \\
{\text { (cal yr B.P. } \pm 1 \text { sigma })^{\mathrm{b}}}\end{array}$ & $\begin{array}{l}\text { Calibrated age } \\
{\text { (cal yr B.P. } \pm 2 \text { sigma })^{\mathrm{b}}}\end{array}$ \\
\hline S-14.5 & 14.5 & aquatic moss & -22.7 & 7117 & $1310 \pm 25$ & $1240 \pm 50$ & $1240 \pm 60$ \\
\hline P-2 & 13 & aquatic moss & -20.9 & 6956 & $1240 \pm 30$ & $1180 \pm 80$ & $1170 \pm 90$ \\
\hline P-27 & 38 & aquatic moss & -23.6 & 7049 & $3460 \pm 25$ & $3740 \pm 90$ & $3740 \pm 90$ \\
\hline P-60 & 71 & aquatic moss & $-25.0^{\mathrm{c}}$ & 7048 & $6450 \pm 35$ & $7370 \pm 48$ & $7360 \pm 70$ \\
\hline P-98 & 109 & aquatic moss & $-25.0^{\mathrm{c}}$ & 7047 & $8150 \pm 40$ & $9070 \pm 50$ & $9130 \pm 120$ \\
\hline $\mathrm{P}-121$ & 132 & aquatic moss & -27.5 & 6955 & $8520 \pm 45$ & $9510 \pm 21$ & $9510 \pm 40$ \\
\hline P-163 & 174 & aquatic moss & -26.0 & 6775 & $9770 \pm 40$ & $11,210 \pm 21$ & $11,200 \pm 50$ \\
\hline
\end{tabular}

${ }^{\text {a }} \mathrm{S}=$ surface core; $\mathrm{P}=$ percussion core.

${ }^{\mathrm{b}}$ Calibrated according to Stuiver and Reimer (1993) and CALIB 5.0.1.

${ }^{\mathrm{c}}$ Estimated value due to insufficient remaining material for measurement. 


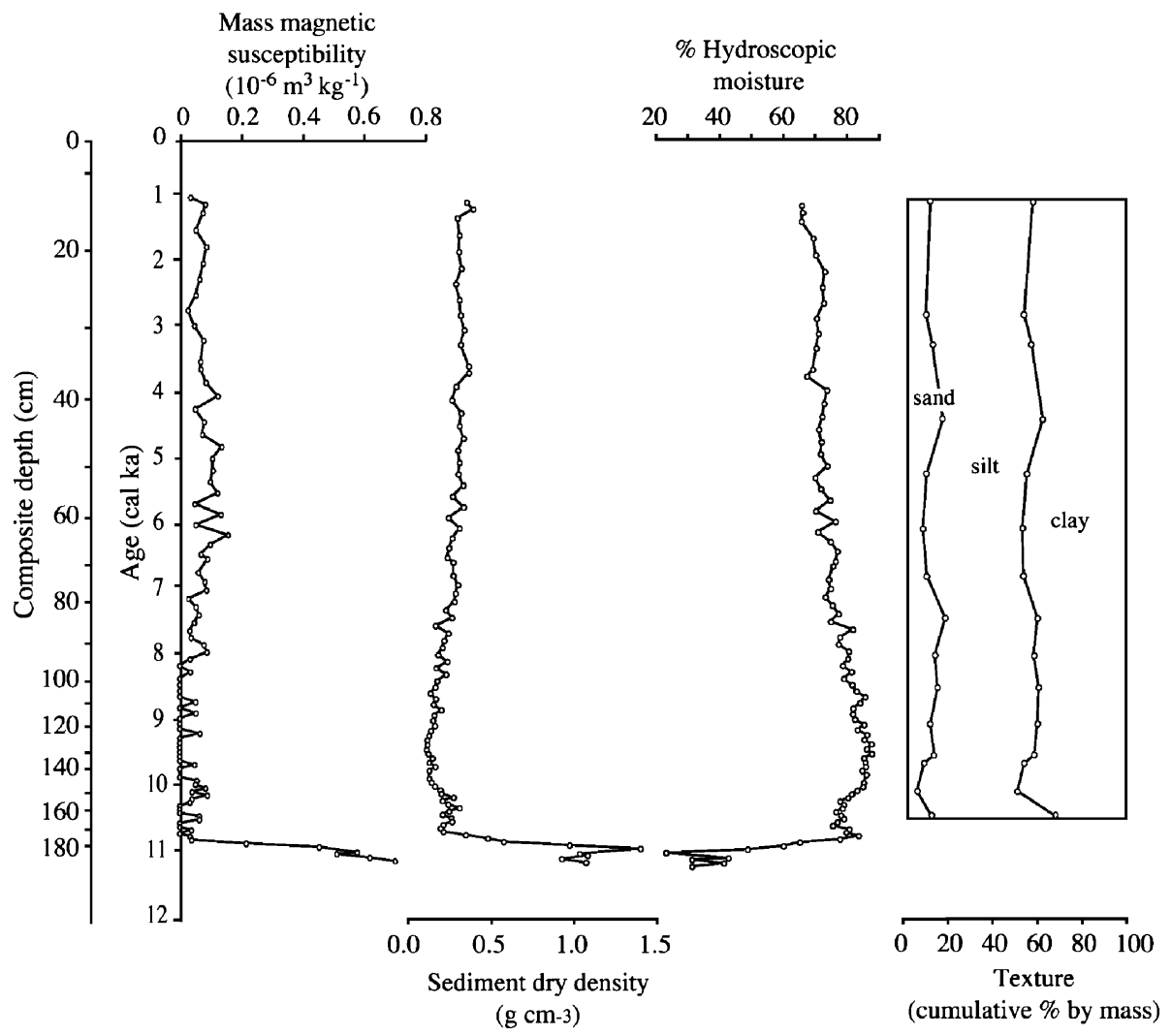

Figure 3. Physical parameters of Lake CF3 percussion core sediments

values $(\sim-1 \%)$ by 10,800 cal yr B.P., and then steadily rise throughout the middle and late Holocene to $\sim 3 \%$.

Chironomid-inferred July air temperature and diatominferred $\mathrm{pH}$ provide quantitative constraints on Holocene environmental variability at Lake CF3. The inferred July air temperatures are based on the shifting chironomid assemblages (Fig. 6). In the earliest part of the Holocene, the chironomid fauna is composed entirely of the subtribe Tanytarsina (Fig. 6).
From $\sim 9500$ to $7000 \mathrm{cal}$ yr B.P., the assemblage also includes Psectrocladius, Tribe Pentaneurini, and Procladius (Figs. 6 and 7). In the late Holocene, there is an increase in Oliveridial Hydrobaenus, Pseudodiamesa, Abiskomyia, Potthastia, and Sergentia (Figs. 6 and 7). A temperature estimate is not possible from the lowermost sample because it consists solely of Tanytarsina and therefore has no analog in the modern training set. The inferred July air temperature is relatively low

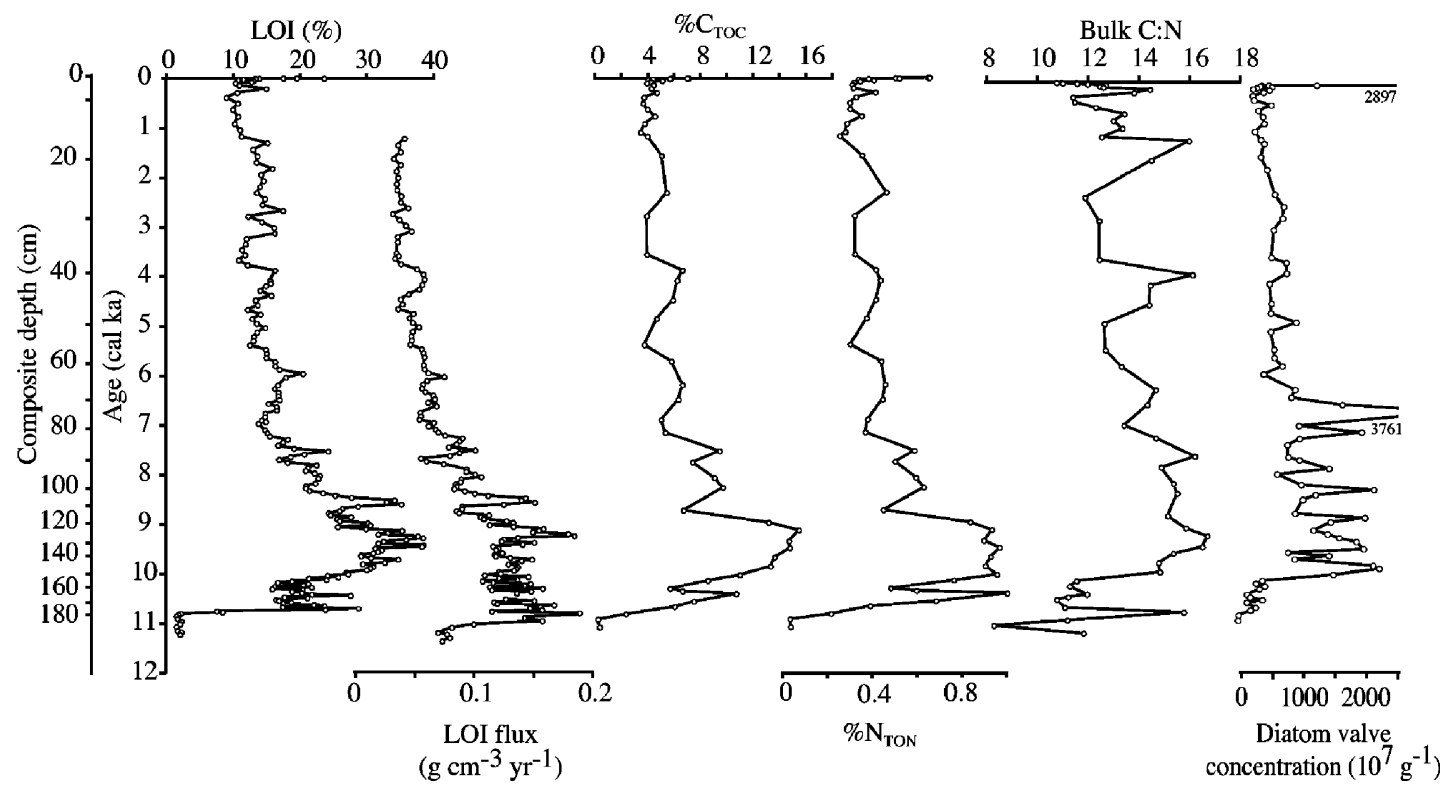

Figure 4. Organic matter parameters of Lake CF3 sediments. 


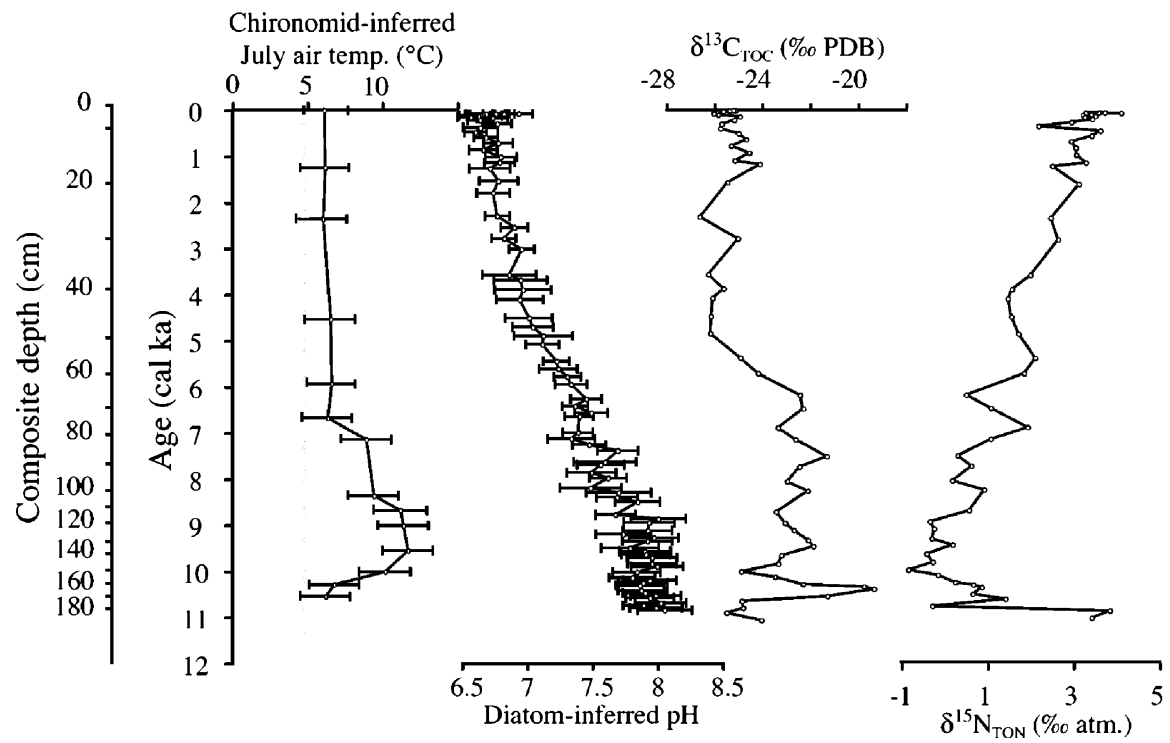

Figure 5. Chironomid-inferred July air temperature and diatom-inferred lakewater pH, and isotopic proxies of Lake CF3 sediments. Vertical dashed line shows modern July air temperature in Clyde River.

between $\sim 10,500$ and $\sim 10,300$ cal yr B.P., is highest $\left(\sim 11^{\circ} \mathrm{C}\right)$ between $\sim 10,000$ and $8500 \mathrm{cal}$ yr B.P., and drops to $\sim 6^{\circ} \mathrm{C}$ by $\sim 7000$ cal yr B.P., a value that is maintained through the late Holocene (Fig. 5). The chironomid-inferred July air temperature in the upper $2 \mathrm{~cm}$ in the surface core is $6.1^{\circ} \mathrm{C}$, $\sim 1.2^{\circ} \mathrm{C}$ warmer than the instrumental record at Clyde River indicates (average July air temperature is $4.9^{\circ} \mathrm{C}$ between 1951 and 1980).

The early Holocene diatom assemblages (Fig. 7) comprised almost entirely $(\sim 80 \%)$ of small, colonial, alkaliphilous Fragilaria sensu lata taxa, including $F$. pinnata, $F$. construens var. venter, and F. pseudoconstruens (e.g., Staurosirella, Staurosira, and Pseudostaurosira). Nitzschia fonticola was also common during this period, although at much lower abundances (typically $<10 \%$ ) than the Fragilaria assemblages. Approximately 5200 cal yr B.P., a more taxonomically diverse, acidophilous assemblage consisting of Pinnularia biceps, Aulacoseria distans, Cavinula pseudoscutiformis, Achnanthes levanderi, Navicula schmassmannii, and N. seminulum, began to increase at the expense of the Fragilaria taxa (Fig. 7). The Fragilaria-dominated assemblage of the early Holocene increased slightly within the last two decades; however, the

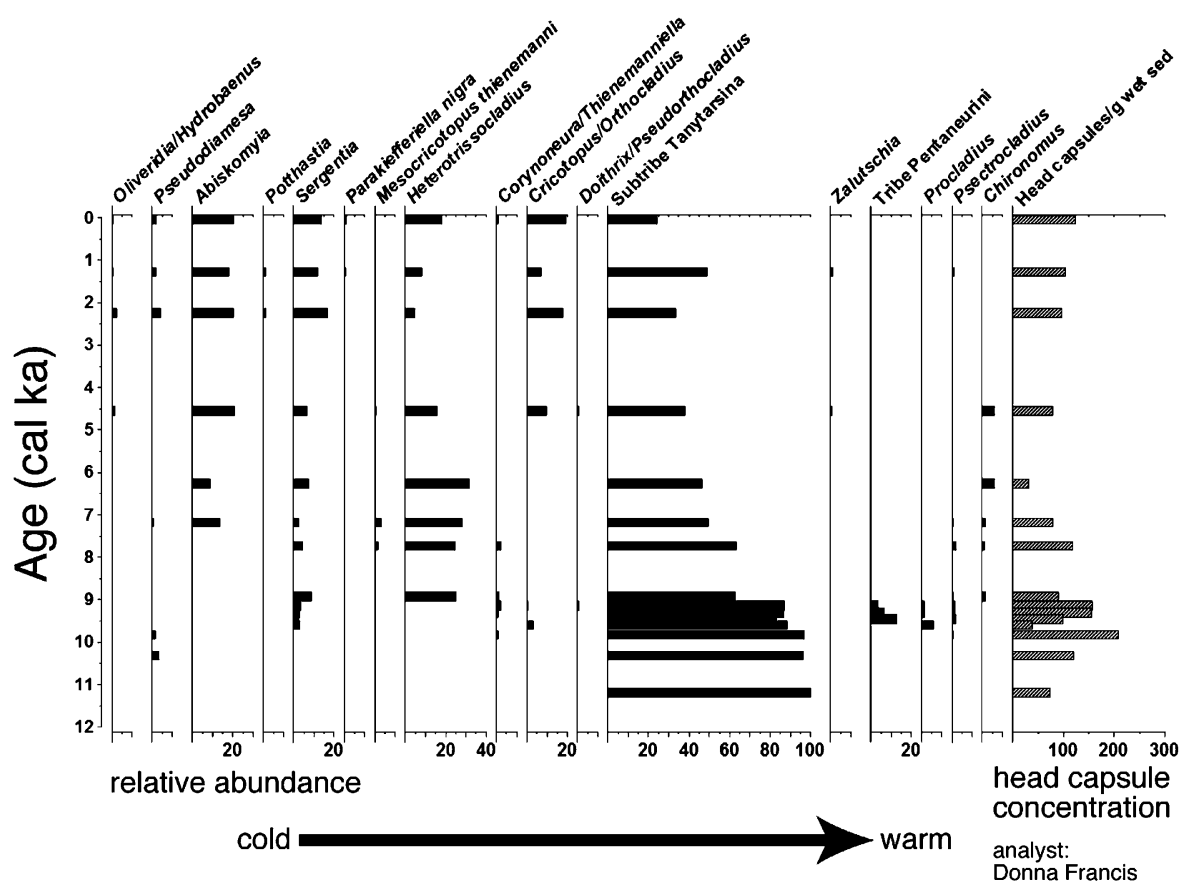

Figure 6. Relative abundances of selected chironomid taxa from Lake CF3 sediments, and concentration of head capsules. Taxa are arranged according to their temperature optima, with cold-water taxa on the left of the diagram. 


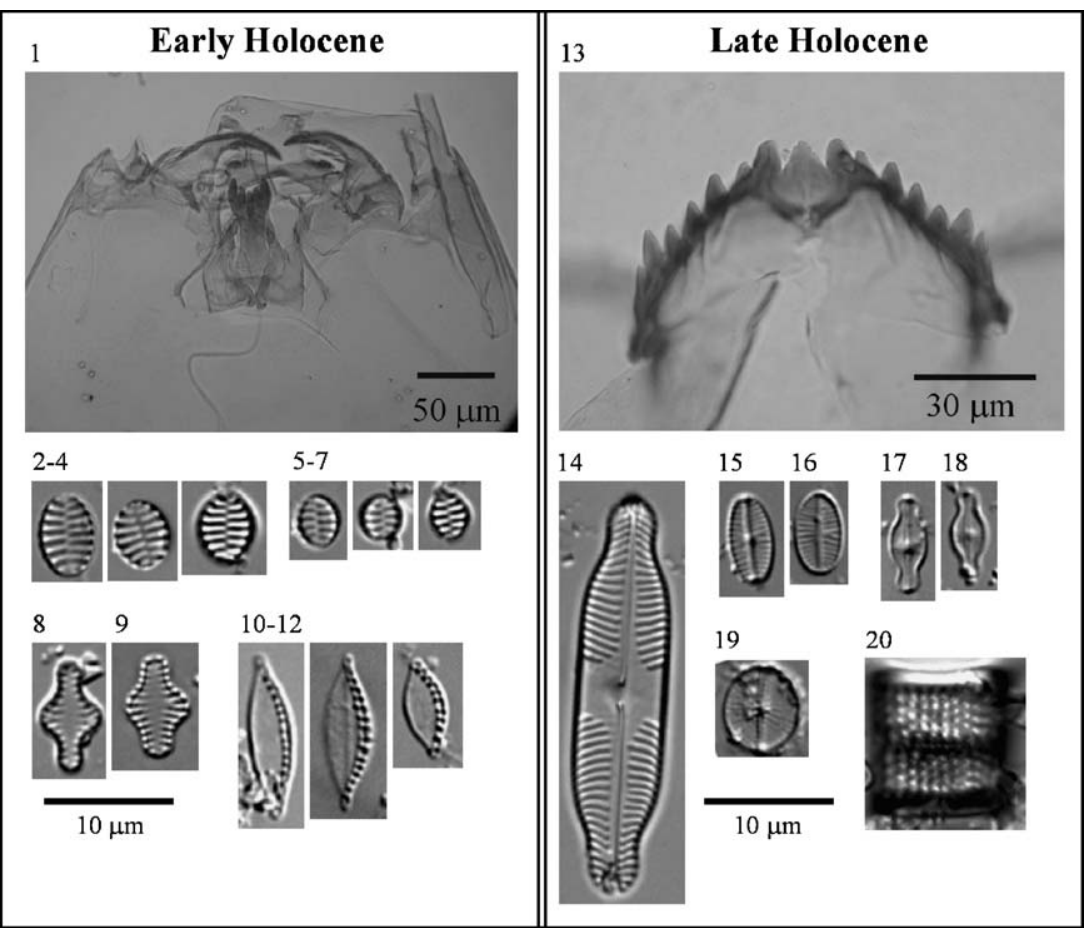

Figure 7. Photomicrographs showing the head capsules of the dominant chironomid taxa (plates 1,13) and diatom assemblages present during the early and late Holocene in Lake CF3. 1 Tribe Pentaneurini. 2-4 Fragilaria construens v. venter (Ehrenberg) Grunow. 5 - 7 F. pinnata Ehrenberg. 8,9 F. pseudoconstruens Marciniak. 10-12 Nitzschia fonticola Grunow. 13 Pseudodiamesa Goetghbuer. 14 Pinnularia biceps Gregory. 15, 16 Achnanthes levanderi Hustedt. 17, 18 Navicula schmassmannii Hustedt. 19 Cavinula pseudoscutiformis Hustedt. 20 Aulacoseira distans (Ehrenberg) Simonsen.

modern diatom assemblage in Lake CF3 is still dominated by acidophilous taxa. Diatom-inferred $\mathrm{pH}$ reveals large changes ranging from $\mathrm{pH} 6.5$ to 8.0 . The highest inferred $\mathrm{pH}$ values occur at the base of the gyttja until $\sim 8500$ cal yr B.P. and gradually decrease thereafter until the recent century, when $\mathrm{pH}$ values increase sharply (Fig. 5).

\section{Discussion}

\section{Holocene environmental change at lake CF3}

The chironomid data provide a quantitative record of Holocene July air temperature at Lake CF3 (Fig. 5) and reveal a period between $\sim 10,000$ and 8500 cal yr B.P. with July air temperatures $\sim 5^{\circ} \mathrm{C}$ warmer than at present. Despite being a relatively low-resolution record, the chironomid-inferred summer temperatures display a well-defined early Holocene thermal maximum (HTM) followed by marked cooling into the middle and late Holocene.

The majority of parameters measured in Lake CF3 sediments relate to organic matter content. All of the organic matter proxies generally follow the chironomid temperature profile, and pronounced increases in organic matter overlap with the chironomid-defined HTM between $\sim 10,000$ and 8500 cal yr B.P. (Fig. 4). The $\% C_{\mathrm{TOC}}$ strongly correlates with chironomid-inferred summer temperature $(r=0.77, P<0.01)$, as is LOI $(r=0.89, P<0.01)$. Thus, it appears that LOI and $\% C_{\mathrm{TOC}}$ record summer temperature at Lake CF3, a finding similar to other studies in high-latitude regions (e.g., Willemse and Törnqvist, 1999; Kaplan et al., 2002). During warmer summers, a shorter duration of lake ice cover and a longer growing season may lead to higher LOI and $\% C$. Because organic matter proxies were measured at a higher resolution than chironomid taxonomy, these proxies can provide a more detailed, albeit qualitative, measure of past summer temperature fluctuations at Lake CF3.

The LOI, $\% C_{\mathrm{TOC}}$, and $\% N_{\mathrm{TON}}$ profiles show the onset of organic matter accumulation beginning $\sim 10,800$ cal yr B.P. Diatom valve concentrations remain relatively low at that time, indicating that Lake CF3 organic matter production was initially dominated by either terrestrial vegetation or aquatic macrophytes. The generally low $C: N$ values during this period are consistent with values derived from an aquatic plant source (aquatic macrophytes or phytoplankton). The lithology indicates the presence of plant macrophytes during this period and the rise in $\delta^{13} C_{\text {TOC }}$ to $\sim-19 \%$ is consistent with an aquatic macrophyte source. The $C: N$ is commonly interpreted as a proxy for the relative contributions of terrestrial versus aquatic organic matter (Meyers and Teranes, 2001). However, because Lake CF3 has such a small, flat catchment with no inflow stream and the surrounding landscape is sparsely vegetated with poorly developed soils, this common interpretation would not be appropriate for Lake CF3. Rather, $C: N$ in Lake CF3 most likely reflects the relative abundance and productivity of differing aquatic plants (phytoplankton and macrophytes). Because of these reasons, and given the abundant aquatic macrophyte layers in the bottommost gyttja in the CF3 sediment core, we infer high aquatic macrophyte production 
during this interval. The LOI, $\% C_{\mathrm{TOC}}$, and $\% N_{\mathrm{TON}}$ values decline between 10,400 and 10,200 cal yr B.P., indicating a reversal in the overall trend of increasing summer temperature. The subsequent increase in chironomid-inferred temperature following 10,200 cal yr B.P. occurs concomitantly with increases in diatom valve concentrations, chironomid headcapsule concentrations, and LOI, $\% C_{\mathrm{TOC}}$, and $\% N_{\mathrm{TON}}$ values, marking the onset of the local HTM.

Following the peak warmth, summer temperature declines through the middle and late Holocene. The LOI, $\% C_{\mathrm{TOC}}$, and $\% N_{\text {TON }}$ values decline in unison $\sim 9000 \mathrm{cal}$ yr B.P., attain relatively low values $\sim 8700$ cal yr B.P., reach near-HTM values $\sim 8600$ cal yr B.P., and then steadily decline to late Holocene values by 7000 or $6000 \mathrm{cal}$ yr B.P. (Fig. 4). Chironomid summer temperatures confirm this pattern, but they do not have the resolution to show the $8700 \mathrm{cal}$ yr B.P. cold period. Interestingly, diatom valve concentrations remain relatively high until $6500 \mathrm{cal}$ yr B.P., indicating high aquatic algae production until the middle Holocene. This corresponds with the $\delta^{13} C_{\text {TOC }}$ values remaining relatively high during this period until $\sim 6000$ cal yr B.P. Relatively low $C: N$ values imply that this stable isotopic signature is being derived from an aquatic source, most likely the diatoms. Although the lowresolution analysis of the chironomids limits the identification of short fluctuations in the middle and late Holocene, LOI, $\% C_{\mathrm{TOC}}$, and $\% N_{\mathrm{TON}}$ values could be used to reveal shorterscale variations. For example, they increase slightly $\sim 6000 \mathrm{cal}$ yr B.P. and decrease slightly between $\sim 4000$ and $3000 \mathrm{cal} \mathrm{yr}$ B.P. (Fig. 4). The LOI, $\% C_{\text {TOC }}$, and $\% N_{\text {TON }}$ values attain their lowest values during the last millennium, except for the last century when they increase. This increase may record recent anthropogenic warming (e.g., Overpeck et al., 1997; Smol et al., 2005). The concentrations of diatom valves also decline toward the last millennium followed by a sharp increase in recent decades (Fig. 4).

Paleolimnological evidence from soft-water alpine and arctic lakes similar to Lake CF3 has shown that lakewater $\mathrm{pH}$ has a direct relationship with climate (Psenner and Schmidt, 1992; Sommaruga-Wögrath et al., 1997; Koinig et al., 1998; Wolfe, 2002). In general, the $\mathrm{pH}$ of these remote lakes has been shown to increase during warm periods and decrease during cool conditions (see Wolfe (2002) for detailed explanation). The poorly buffered nature of Lake CF3 (dissolved inorganic carbon $=0.96 \mathrm{mg} / \mathrm{L}$ ) suggests that it is particularly susceptible to climate-driven shifts in $\mathrm{pH}$ and, as such, diatom-inferred $\mathrm{pH}$ can be used as an indirect measure of past temperature fluctuations. The diatom-inferred $\mathrm{pH}$ at Lake CF3 appears to react to Holocene climatic fluctuations, based on our present understanding of climate- $\mathrm{pH}$ relationships in soft-water arctic lakes. In general, the diatom-inferred $\mathrm{pH}$ is in good agreement with the other temperature proxies showing highest values during the HTM and gradually declining values throughout the much cooler middle and late Holocene (Fig. 5).

The stratigraphies of $\delta^{13} C_{\mathrm{TOC}}$ and $\delta^{15} N_{\mathrm{TON}}$ appear to be primarily mediated by changes in lake primary production, which in turn can been linked to climate on a variety of timescales (Flanagan et al., 2003; Wolfe et al., 2003). Overall, $\delta^{13} C_{\text {TOC }}$ values are considerably higher in the early Holocene relative to the late Holocene, by as much as $4 \%$ (Fig. 5). This is consistent with enhanced aquatic production during the early Holocene, because greater photosynthetic drawdown of the dissolved inorganic carbon (DIC) pool will reduce the ability of autotrophs to physiologically fractionate against the heavy isotope (Schelske and Hodell, 1995). This is well supported by the coherence between the highest $\delta^{13} C_{\text {TOC }}$ values and peak diatom valve concentrations, which are commonly the dominant algal group in arctic lakes. This scenario is further supported by elevated early Holocene diatom-inferred $\mathrm{pH}$ values, since photosynthetic drawdown of $\mathrm{CO}_{2}$ has the consequence of raising lake $\mathrm{pH}$, to which diatom assemblages respond ecologically (Wolfe, 2002).

The interpretation of $\delta^{15} N_{\text {TON }}$ values is less straightforward, in part because there is general antiphasing between the $\delta^{13} C_{\text {TOC }}$ and $\delta^{15} N_{\text {TON }}$ records (Fig. 5). For the early Holocene, this is not the expected pattern under conditions of enhanced algal production, since $\delta^{15} N_{\text {TON }}$ would predictably become isotopically enriched, not depleted, with enhanced utilization of available nitrogen sources (Hodell and Schelske, 1998). There are several alternative explanations for the exceptionally light $\delta^{15} N_{\text {TON }}$ values observed in the $\sim 10,000$ to $8500 \mathrm{cal}$ yr B.P. interval in Lake CF3, with fundamentally different implications for the lake's paleolimnological regime. First, major contributions of $\mathrm{N}_{2}$-fixing cyanobacteria to sediment organic matter may be responsible, as these algae produce low $\delta^{15} N_{\mathrm{TON}}$ organic matter (Talbot, 2001). Second, dissolved inorganic nitrogen (DIN) concentrations may have been sufficiently high to enable sustained physiological fractionation against $\delta^{15} N_{\text {TON }}$, even under the relatively productive conditions inferred from complementary proxies. We ultimately favor the second hypothesis for several reasons. There is no compelling evidence for either cyanobacterial domination or $N$ limitation in the early Holocene. Sediment $C: N$ exceeds 14 throughout this interval (Fig. 4), which is inconsistent with major cyanobacterial contributions, given the high $N$ content of their cells (Talbot, 2001). We also note that the total $N: P$ mass ratio of modern Lake CF3 water is 57 , suggesting currently strong limitation with respect to $P$ and not $N$. Although different resource ratios are possible, and even likely, for the early Holocene, it seems likely that $P$ limitation has been a pervasive feature of this lake. Indeed, sustained $P$ limitation appears consistent with low $\delta^{15} N_{\text {TON }}$ in a range of organic fractions in lakes, including sediments (Jones et al., 2004). We thus surmise that the low $\delta^{15} N_{\text {TON }}$ values that characterize the HTM in Lake CF3 reflect, primarily, a sufficiently large available $N$ pool so that $N$ was never limiting, despite the elevated primary production suggested by the diatom and $\delta^{13} C_{\text {TOC }}$ data. Alternatively, the low $\delta^{15} N_{\mathrm{TON}}$ values result from increased seasonal difference between warm summers and cold winters, leading to enhanced mixing and ventilation of Lake CF3, which could minimize or even prevent denitrification. This increased mixing would also magnify lake productivity. This notion of increased seasonal mixing would explain why higher lake productivity, warmer summer temperatures, 
and low $\delta^{15} N_{\text {TON }}$ values correspond in Lake CF3. In any case, sediment $\delta^{15} N_{\text {TON }}$ values remain intimately linked to aquatic production and climate, as suggested by correlations between $\delta^{15} N_{\mathrm{TON}}$ and other proxies of paleo-production, including $\% C_{\mathrm{TOC}}(r=-0.77, P<0.01), \% N_{\mathrm{TON}}(r=-0.78$, $P<0.01)$ and diatom-inferred $\mathrm{pH}(r=-0.92, P<0.01)$.

\section{Holocene climate in the Baffin bay region}

This study offers a high-resolution lacustrine Holocene climate record that spans the last $\sim 11,200$ years. The most notable feature of Holocene climate at Lake CF3 was the welldefined HTM between $\sim 10,000$ and 8500 cal yr B.P., when chironomid-inferred summer temperature was $\sim 5^{\circ} \mathrm{C}$ warmer than today and the duration of seasonal lake ice cover probably was the shortest since deglaciation (Fig. 8). Pollen records from several Baffin Island lakes indicate middle Holocene temperatures $\sim 1$ or $2^{\circ} \mathrm{C}$ warmer than present (Kerwin et al., 2004). Because pollen-based temperature reconstructions rarely extend beyond 7 or $8 \mathrm{ka}$, they may not capture maximum Holocene warmth. Chironomid taxonomy- and $\delta^{18} \mathrm{O}$-based summer temperatures from Qipisarqo Lake on southern Greenland (Fig. 1) indicate that conditions were 2 to $4^{\circ} \mathrm{C}$ warmer in the early Holocene versus the late Holocene (Wooller et al., 2004). Diatom-inferred temperature data from Fog Lake, $\sim 420 \mathrm{~km}$ south of Lake CF3 (Fig. 1), reveal a $\sim 4^{\circ} \mathrm{C}$ difference between the middle and late Holocene (Joynt and Wolfe, 2001). Dynocyst assemblages from northern Baffin Bay marine cores reveal $\sim 5^{\circ} \mathrm{C}$ difference in sea surface temperature (SST) between the middle and late Holocene (Levac et al., 2001). Greenland ice sheet borehole paleothermometry indicates a temperature change of $\sim 3.5^{\circ} \mathrm{C}$ between the middle and late Holocene (Dahl-Jensen et al., 1998). Thus, the magnitude of HTM warmth at Lake CF3 is apparently larger than existing records reveal. It is possible that Lake CF3 was exceptionally sensitive to early Holocene insolation forcing due to its small size.

The structure of summer temperature change at Lake CF3early Holocene peak warmth followed by modest cooling beginning as early as 9000 or $8000 \mathrm{cal} \mathrm{yr} \mathrm{B.P.--is} \mathrm{atypical} \mathrm{for}$ the Baffin Bay region. Most records of Holocene environmental change reveal a more subdued HTM, with peak temperatures during the middle rather than early Holocene (Kaufman et al., 2004). Pollen-inferred July temperatures that span 7500 to $2600 \mathrm{cal}$ yr B.P. from Patricia Bay Lake, $9.5 \mathrm{~km}$ from Lake CF3 (Fig. 1), reveal temperatures decreasing by $\sim 2^{\circ} \mathrm{C}$ (Kerwin et al., 2004) and a trend similar to $\mathrm{CF} 3$ proxies (Fig. 8). Many Lake CF3 proxies (e.g., chironomid-based temperature, LOI, $\% C_{\mathrm{TOC}}$, and $\% N_{\mathrm{TON}}$, and diatom-inferred $\mathrm{pH})$ are similar in trend and structure to the melt layer record from the Agassiz ice cap (Fig. 8; Fisher and Koerner, 2003). The Agassiz melt record shows the onset of summer snowmelt $\sim 11,000$ cal yr B.P. and peak melt percentages between 10,200 and 9500 cal yr B.P. (Fig. 8; Fisher and Koerner, 2003). In contrast, the Agassiz $\delta^{18} \mathrm{O}$ record suggests slower climate amelioration following regional deglaciation, a broader period of elevated temperatures during the middle Holocene, and a later decline of temperatures during the late Holocene (Fig. 8; Fisher et al., 1995). This overall pattern is expressed in other records of Holocene climate change in western arctic regions (Kaufman et al., 2004).

One possible explanation for the discrepancy among the different paleoclimate reconstructions (e.g., middle versus late HTM) involves the seasons that each particular proxy records.

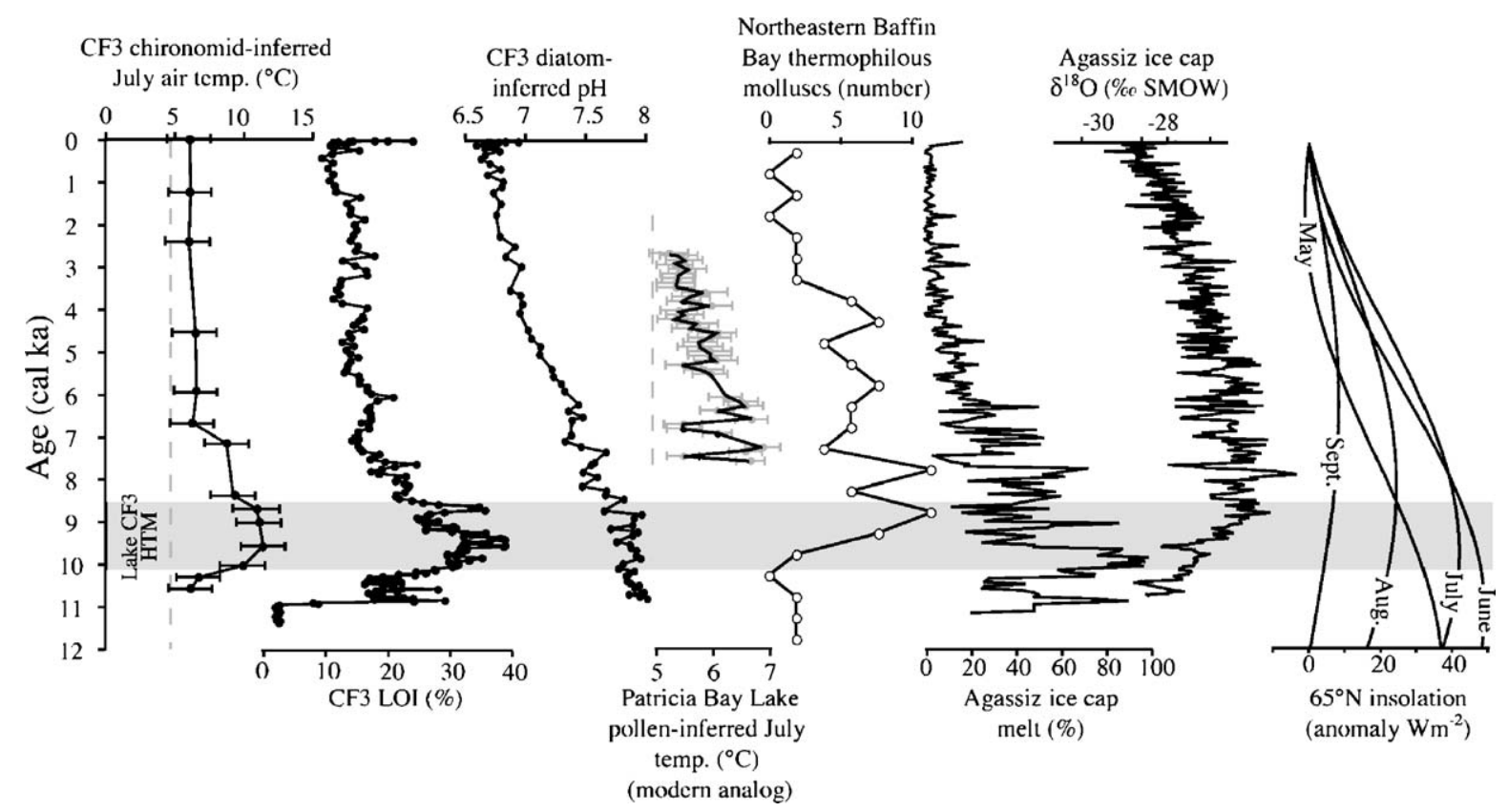

Figure 8. Lake CF3 proxies compared to other climate records from the Baffin Bay region and high-latitude summer insolation. Seasonality is shown by the difference in insolation anomaly values between months. Vertical dashed line shows modern July air temperature in Clyde River. Paticia Bay Lake pollen from Kerwin et al. (2004); Baffin Bay mollusks from Dyke et al. (1996); Agassiz data from Fisher et al. (1995); insolation data from Berger and Loutre (1991). 
For example, Agassiz ice cap $\delta^{18} \mathrm{O}$ values are recording precipitation over the entire year, whereas melt layers are formed only during the warmest summer months. Because seasonality was greater in the early Holocene than at present (Berger and Loutre, 1991; Fig. 8), proxies that record only summer conditions may show more pronounced early Holocene warmth than those that record mean annual conditions. This explanation is consistent with our findings of an early HTM at Lake CF3, as these lake proxies effectively record only summer conditions due to the extensive snow and ice coverage for $\sim 9$ months of the year.

The pronounced and relatively early HTM recorded at Lake CF3 stands in contrast to records of Baffin Bay oceanographic conditions. The HTM at Lake CF3, only $2.7 \mathrm{~km}$ from Baffin Bay, occurred $\geq 1000$ years before northeastern Baffin Bay received the maximum advection of relatively warm North Atlantic water (via the WGC), which is recorded by the population of radiocarbon-dated thermophilous mollusk (Fig. 8; Dyke et al., 1996) and dynocyst (Levac et al., 2001) assemblages. Perhaps Baffin Bay itself was kept cool during the early Holocene by Laurentide Ice Sheet meltwater. The maximum warmth at Lake $\mathrm{CF} 3$ also occurred when outlet glaciers still filled adjacent fjords (Briner, 2003; Briner et al., 2005), indicating a minimal influence of the retreating LIS on coastal Baffin Island sites during the earliest Holocene. High summer insolation and seasonality, rather than the relative warmth of the adjacent ocean, were the predominant climate forcings on lacustrine environments on eastern Baffin Island during the early Holocene.

\section{Conclusions}

Multiple proxies in Lake CF3 sediments indicate an early HTM $5^{\circ} \mathrm{C}$ warmer than present, which ended $\sim 8500$ cal yr B.P. in a rapid cooling followed by more gradual cooling that continued until the last century. This finding is strengthened by several independent chemical and biological proxies that indicate the same overall trend. The high correlation between percentages of organic matter and chironomid-inferred summer temperatures indicates that the $\% C\left(\% C_{\mathrm{TOC}}\right.$ or approximation by LOI) may be a potentially sensitive recorder of past summer temperature in lakes similar to Lake CF3. Given the many lakes with similar morphological and limnological characteristics to Lake CF3 on eastern Baffin Island, this finding has implications for the potential use of $\% C$ measurements to increase the spatial coverage of Holocene climate reconstructions from this region.

Lake CF3 sediments register an HTM earlier than in many other records from northeastern North America (Kaufman et al., 2004). Middle Holocene warmth recorded in many arctic regions has been attributed to delayed warming due to the influence of the decaying Laurentide Ice Sheet during the earliest Holocene. This influence may be most important for proxies responding to oceanic conditions, such as ocean floral and faunal assemblages. On the other hand, lacustrine proxies such as organic matter, chironomids and diatoms, which primarily record local summer conditions, likely reflect insolation-driven warmth in the early Holocene despite the proximity of waning ice sheets.

\section{Acknowledgments}

We thank Allison Forrest and Wendy Freeman for assistance with sediment analysis at INSTAAR, Jocelyn Turnbull for assistance with preparation of materials for radiocarbon dating, and Jamesee Qillaq, Jason Hainnu, and other friendly Inuit of Clyde River for logistical support. We thank P. Meyers and an anonymous reviewer for strengthening the manuscript. We appreciate the permitting and logistical support provided by the Nunavut Research Institute and the National Science Foundation.

\section{References}

Barlow, L.K., Sadler, J.P., Ogilvie, A.E.J., Buckland, P.C., Amorosi, T., Ingimundarson, J.H., Skidmore, P., Dugmore, A.J., McGover, T.H., 1997. Interdisciplinary investigations of the end of the Norse western settlement in Greenland. The Holocene 7, 489-499.

Bennike, O., 2000. Palaeoecological studies of Holocene lake sediments from west Greenland. Palaeogeography Palaeoclimatology Palaeoecology 155, 285-304.

Berger, A., Loutre, M.F., 1991. Insolation values for the climate of the last 10 million years. Quaternary Science Reviews 10, 291-310.

Bigler, C., Larocque, I., Peglar, S.M., Birks, H.J.B., Hall, R.I., 2002. Quantitative multiproxy assessment of long-term patterns of Holocene environmental change from a small lake near Abisko, northern Sweden. The Holocene 12, 481-496.

Bond, G., Kromer, B., Beer, J., Muscheler, R., Evans, M., Showers, W., Hoffmann, S., Lotti-Bond, R., Hajdas, I., Bonani, G., 2001. Persistent solar influence on North Atlantic climate during the Holocene. Science 294, $2130-2136$.

Briner, J.P., 2003. The Last Glaciation of the Clyde Region, Northeastern Baffin Island, Arctic Canada: Cosmogenic Isotope Constraints on Laurentide Ice Sheet Dynamics and Chronology [PhD thesis]. University of Colorado, Boulder. 300 p.

Briner, J.P., Miller, G.H., Davis, P.T., Finkel, R., 2005. Cosmogenic exposure dating in arctic glacial landscapes: implications for the glacial history of northeastern Baffin Island, Arctic Canada. Canadian Journal of Earth Sciences 42, 67-84.

CAPE Project Members, 2001. Holocene paleoclimate data from the Arctic: testing models of global climate change. Quaternary Science Reviews 20, $1275-1287$.

Dahl-Jensen, D., Mosegaard, K., Gundestrup, G., Clow, G.D., Johnson, SJ., Hansen, A.W., Balling, B., 1998. Past temperature directly from the Greenland ice sheet. Science 282, 268-271.

Dean Jr., W.E., 1974. Determination of carbonate and organic matter in calcareous sediments and sedimentary rocks by loss on ignition: comparison with other methods. Journal of Sedimentary Petrology 44, $242-248$.

Dyke, A.S., Dale, J.E., McNeely, R.N., 1996. Marine molluscs as indicators of environmental change in glaciated North America and Greenland during the last 18,000 years. Géographie Physique et Quaternaire 50, $125-184$.

Dyke, A.S., Andrews, J.T., Clark, P.U., England, J.H., Miller, G.H., Shaw, J., Veillette, J.J., 2002. The Laurentide and Innuitian ice sheets during the Last Glacial Maximum. Quaternary Science Reviews 21, 9-31.

Fisher, D.A., Koerner, R.M., 2003. Holocene ice core climate history, a multi-variable approach. In: Mackay, A., Battarbee, R., Birks, J., Oldfield, F. (Eds.), Global Change in the Holocene. Arnold, London, pp. $281-293$. 
Fisher, D.A., Koerner, R.M., Reeh, N., 1995. Holocene climatic records from Agassiz Ice Cap, Ellesmere Island, NWT, Canada. The Holocene $5,19-24$.

Fisher, D.A., Koerner, R.M., Bourgeois, J.C., Zielinski, G., Wake, C., Hammer, C.U., Clausen, H.B., Gundestrup, N., Johnsen, S., Goto-Azuma, K., Hondoh, T., Blake, E., Gerasimoff, M., 1998. Penny ice cap cores, Baffin Island, Canada, and the Wisconsinan Foxe Dome connection: two states of Hudson Bay ice cover. Science 279, 692-695.

Flanagan, K.M., McCauley, E., Wrona, F., Prowse, T., 2003. Climate change: the potential for latitudinal effects on algal biomass in aquatic ecosystems. Canadian Journal of Fisheries and Aquatic Sciences 60, 635-639.

Harris, D., Howarth, W.R., van Kessel, C., 2001. Acid fumigation of soils to remove carbonates prior to total organic carbon or carbon-13 isotopic analysis. Soil Science Society of America Journal 65, 1853-1856.

Heiri, O., Lotter, A.F., Lemcke, G., 2001. Loss on ignition as a method for estimating organic and carbonate content in sediments: reproducibility and compatibility of results. Journal of Paleolimnology 25, 101-110.

Hodell, D.A., Schelske, C.L., 1998. Production, sedimentation, and isotopic composition of organic matter in Lake Ontario. Limnology and Oceanography $43,200-214$.

Jacobs, J.D., Andrews, J.T., 1985. Environmental background. In: Andrews, J.T. (Ed.), Quaternary Environments: Eastern Canadian Arctic, Baffin Bay and Western Greenland. Allen and Unwin, Boston, pp. 26-68.

Jones, R.I., King, L., Dent, M.M., Maberly, S.C., Gibson, C.E., 2004. Nitrogen stable isotope ratios in surface sediments, epilithon and macrophytes from upland lakes with differing nutrient status. Freshwater Biology 49, 382-391.

Joynt III, E.H., Wolfe, A.P., 2001. Paleoenvironmental inference models from sediment diatom assemblages in Baffin Island lakes (Nunavut, Canada), with special reference to the reconstruction of summer water temperature. Canadian Journal of Fisheries and Aquatic Sciences 58, 1222-1243.

Juggins, S., 2003. C2 Data Analysis v1.3 (software). University of Newcastle.

Kaplan, M.R., Wolfe, A.P., Miller, G.H., 2002. Holocene environmental variability in southern Greenland inferred from lake sediments. Quaternary Research 58, 149-159.

Kaufman, D.S., Ager, T.A., Anderson, N.J., Anderson, P.M., Andrews, J.T., Bartlein, P.T., Brubaker, L.B., Coats, L.L., Cwynar, L.C., Duvall, M.L., Dyke, A.S., Edwards, M.E., Eisner, W.R., Gajewski, K., Geirsdottir, A., Hu, F.S., Jennings, A.E., Kaplan, M.R., Kerwin, M.W., Lozhkin, A.V., MacDonald, G.M., Miller, G.H., Mock, C.J., Oswald, W.W., Otto-Bliesner, B.L., Porinchu, D.F., Ruhland, K., Smol, J.P., Steig, E.J., Wolfe, B.B., 2004. Holocene thermal maximum in the western Arctic (0-180 degrees W) Quaternary Science Reviews 23, 2059-2060.

Kelly, M., 1985. A review of the Quaternary Geology of western Greenland. In: Andrews, J.T. (Ed.), Quaternary Environments: Eastern Canadian Arctic, Baffin Bay and Western Greenland. Allen and Unwin, Boston, pp. 461-501.

Kerwin, M.W., Overpeck, J.T., Webb, R.S., Anderson, K.H., 2004. Pollenbased summer temperature reconstructions for the eastern Canadian boreal forest, subarctic, and Arctic. Quaternary Science Reviews 23, 1901-1924.

Koinig, K.A., Schmidt, R., Sammaruga-Wögrath, S., Tessadri, R., Psenner, R., 1998. Climate change as the primary cause for $\mathrm{pH}$ shifts in a high arctic lake. Water Air and Soil Pollution 104, 167-180.

Krammer, K., Lange-Bertalot, H., 1986-1991. Bacillariophyceae. In: Ettl, H., Gerloff, J., Heynig, D., Mollenhauer, D.Sußwasserflora von Mitteleuropa vol. 2 (1-4). Gustav Fischer Verlag, Stuttgart/Jena.

Larocque, I., Bigler, C., 2004. Similarities and discrepancies between chrionomid- and diatom-inferred temperature reconstructions through the Holocene at Lake 850, northern Sweden. Quaternary International 122, $109-121$.

Levac, E., de Vernal, A., Blake Jr., W., 2001. Sea-surface conditions in northernmost Baffin Bay during the Holocene: palynological evidence. Journal of Quaternary Science 16, 353-363.

Meyers, P.A., Teranes, J.L., 2001. Sediment organic matter. In: Last, W.M., Smol, J.P. (Eds.), Tracking Environmental Change Using Lake Sediments. Kluwer Academic Publishers, pp. 239-270.

Miller, G.H., Mode, W.N., Wolfe, A.P., Sauer, P.E., Bennike, O., Forman, S.L., Short, S.K., Stafford Jr., T.W., 1999. Stratified interglacial lacustrine sediments from Baffin Island, Arctic Canada: chronology and paleoenvironmental implications. Quaternary Science Reviews 18, $789-810$.

Moritz, R.E., Bitz, C.M., Steig, E.J., 2002. Dynamics of recent climate change in the Arctic. Science 297, 1497-1502.

Nesje, A., 1992. A piston corer for lacustrine and marine sediments. Arctic and Alpine Research 24, 257-259.

Overpeck, J., Hughen, K., Hardy, D., Bradley, R., Case, R., Douglas, M., Finney, B., Gajewski, K., Jacoby, G., Jennings, A., Lamoureux, S., Lasca, A., MacDonald, G., Moore, J., Retelle, M., Smith, S., Wolfe, A., Zielinski, G., 1997. Arctic environmental change of the last four centuries. Science 278, 1251-1256.

Patrick, R., Reimer, C.W., 1966. The diatoms of the United States exclusive of Alaska and Hawaii, vol. 1. Academy of Natural Sciences of Philadelphia. Monograph No. 13

Patrick, R., Reimer, C.W., 1975. The diatoms of the United States exclusive of Alaska and Hawaii, vol. 2. Academy of Natural Sciences of Philadelphia. Monograph No. 13.

Psenner, R., Schmidt, R., 1992. Climate-driven pH control of remote alpine lakes and effects of acid deposition. Nature 356, 781-783.

Rosén, P., Segerstrom, U., Eriksson, L., Renberg, I., Birks, H.J.B., 2001. Holocene climatic change reconstructed from diatoms, chironomids, pollen and near-infrared spectroscopy at an alpine lake (Sjuodjijaure) in northern Sweden. The Holocene 11, 551-562.

Schelske, C.L., Hodell, D.A., 1995. Using carbon isotopes of bulk sedimentary organic matter to reconstruct the history of nutrient loading and eutrophication in Lake Erie. Limnology and Oceanography 40, 918-929.

Smol, J.P., Wolfe, A.P., Birks, H.J.B., Douglas, M.S.V., Jones, V.J., Korhola, A., Pienitz, R., Ruhland, K., Sorvari, S., Antoniades, D., Brooks, S.J., Fallu, M.A., Hughes, M., Keatley, B.E., Laing, T.E., Michelutti, N., Nazarova, L., Nyman, M., Paterson, A.M., Perren, B., Quinlan, R., Rautio, M., SaulnierTalbot, E., Siitoneni, S., Solovieva, N., Weckstrom, J., 2005. Climatedriven regime shifts in the biological communities of arctic lakes. Proceedings of the National Academy of Sciences of the United States of America 102, 4397-4402.

Sommaruga-Wögrath, S., Koinig, K., Schmidt, R., Sommaruga, R., Tessadri, R., Psenner, R., 1997. Temperature effects on the acidity of remote alpine lakes. Nature 387, 64-67.

Stuiver, M., Reimer, P.J., 1993. Extended C-14 data-base and revised CALIB 3.0 C-14 age calibration program. Radiocarbon 35, 215-230.

Talbot, M.R., 2001. Nitrogen isotopes in palaeolimnology. In: Last, W.M., Smol, J.P. (Eds.), Tracking Environmental Change Using Lake Sediments, Physical and Geochemical Techniques, vol. 2. Kluwer Academic Publishers, Dordrecht, pp. 401-439.

Walker, I.R., 2001. Midges: chironomidae and related Diptera. In: Smol, J.P., Birks, H.J.B., Last, W.M. (Eds.), Tracking Environmental Change in Lake Sediments, Zoological Indicators, vol. 4. Kluwer Academic Publishers, Dordrecht, pp. 43-66.

Walker, I.R., Leveque, A.J., Cwynar, L.C., Lotter, A.F., 1997. An expanded surface-water palaeotemperature inference model for use with fossil midges from eastern Canada. Journal of Paleolimnology 18, 165-178.

Willemse, N.W., Törnqvist, T.E., 1999. Holocene century-scale temperature variability from West Greenland lake records. Geology 27, 580-584.

Wilson, S.B., Cumming, B.F., Smol, J.P., 1996. Assessing the reliability of salinity inference models from diatom assemblages: an examination of a 219 lake dataset from western North America. Canadian Journal of Fisheries and Aquatic Sciences 53, 1580-1594.

Wolfe, A.P., 1996. A high resolution late-glacial and early Holocene diatom record from Baffin Island, eastern Canadian Arctic. Canadian Journal of Earth Sciences 33, 928-937.

Wolfe, A.P., 2002. Climate modulates the acidity of arctic lakes on millennial time scales. Geology, 215-218.

Wolfe, A.P., Fréchette, B., Richard, P.J.H., Miller, G.H., Forman, S.L., 2000. Paleoecological Assessment of a $>90,000$-year record from Fog Lake, Baffin Island, Arctic Canada. Quaternary Science Reviews 19, $1677-1699$.

Wolfe, A.P., Van Gorp, A.C., Baron, J.S., 2003. Recent ecological and 
biogeochemical changes in alpine lakes of Rocky Mountain National Park (Colorado, USA): a response to anthropogenic nitrogen deposition. Geobiology 1, 153-168.

Wolfe, A.P., Miller, G.H., Olsen, C.A., Forman, S.L., Doran, P.T., Holmgren, S.U., 2004. Geochronology of high latitude lake sediments. In: Pienitz, R., Douglas, M.S.V., Smol, J.P. (Eds.), Long-term Environmental Change in
Arctic and Antarctic Lakes. Kluwer Academic Publishers, Dordrecht, The Netherlands, pp. 1-32.

Wooller, M.J., Francis, D., Fogel, M.L., Miller, G.H., Walker, I.R., Wolfe, A.P., 2004. Quantitative paleotemperature estimates from ${ }^{18} \mathrm{O}$ of chironomid head capsules preserved in arctic lake sediments. Journal of Paleolimnology $31,267-274$. 